\title{
Comparative evaluation of Salicornia bigelovii oil planted under different treatments
}

\author{
R. El-Araby ${ }^{1 *}$, A. I. Rezk², S. A. Abo El-Enin ${ }^{1}$, O. A. Nofal ${ }^{3}$ and A. B. El-Nasharty ${ }^{2}$
}

\begin{abstract}
Background: Assessment of the oil \% in a representative sample of Salicornia bigelovii seeds with different extraction methods using some of the organic solvents to reach the best economic one and determination of the effect of S. bigelovii cultivation under different conditions of irrigation and fertilization on the percentage, composition, and nutrition value of oil were done. From the International Training Centre-Mariut, Alexandria, we obtained representative samples of Salicornia bigelovii seeds which are collected from the sea coast and 17 samples of S. bigelovii seeds which are subjected to different treatments of irrigation and fertilization. The oil \% in a blank sample (B) was determined using different solvents (hexane, hexane-isopropanol, and ethanol) with variant methods (shaker, conventional, and ultrasonic). Oil \% in 17 samples was evaluated by the ultrasonic probe technique using ethanol. The oil composition was determined in all samples by GC analysis. The phenolic and flavonoid contents in the residue were determined with the Folin-Ciocalteu reagent and colorimetric method, respectively.

Results: The ethanol has higher extraction efficiency and the ultrasonic probe recovered higher oil \% in the blank sample. Seventeen samples of S. bigelovii cultivated under different combined treatments of fertilization and irrigation recorded oil \% less than the blank sample. The fatty acids profile cleared that the oil of cultivated samples (17 samples) had power for biodiesel production with high ignition properties and good stability due to the high cetane number and a high percentage of palmitic acid. The nutrition value of the blank sample is higher than that of the other 17 samples. The polyunsaturated fatty acids in the blank sample represent $>63 \%$ of the total fatty acids.

Conclusion: The different combined treatments of fertilization and irrigation of S. bigelovii changed the fatty acid profiles of all samples, palmitic, stearic, oleic, and linoleic acids were recognized as the most abundant saturated fatty acids. The total phenolic and flavonoid contents differed in the sample to another one but less than their contents in the blank sample.
\end{abstract}

Keywords: Cultivation, Fatty acids, Halophyte plants, Nutrition value, Oil extraction, Salicornia bigelovii

\section{Background}

One of the problems facing the world is how to provide food needs in the frame of limiting soils for cultivation and not enough water sources with increasing population problem. Egypt, like other developing countries of the

\footnotetext{
* Correspondence: rehamelaraby@hotmail.com

${ }^{1}$ Chemical Engineering and Pilot Plant National Research Centre, Giza, Egypt Full list of author information is available at the end of the article
}

arid and semi-arid regions, faces four major problems, namely high rate of population increases, limited natural sources of good quality water, the existence of salt-affected land, and shortage of food and feed (Koyro et al., 2011). In the agriculture regions, the change in the climate of a decrease in rainfall and an increase in temperature means a water crisis (Fan et al., 2014). Therefore, it requires a change in the established

\section{Springer Open}

(ㅇ The Author(s). 2020 Open Access This article is licensed under a Creative Commons Attribution 4.0 International License, which permits use, sharing, adaptation, distribution and reproduction in any medium or format, as long as you give appropriate credit to the original author(s) and the source, provide a link to the Creative Commons licence, and indicate if changes were made. The images or other third party material in this article are included in the article's Creative Commons licence, unless indicated otherwise in a credit line to the material. If material is not included in the article's Creative Commons licence and your intended use is not permitted by statutory regulation or exceeds the permitted use, you will need to obtain permission directly from the copyright holder. To view a copy of this licence, visit http://creativecommons.org/licenses/by/4.0/. 
agricultural operations management and taking the nontraditional direction to maintain productivity and increase sustainability (García-Caparrós et al., 2018).

The recent technique for solving many of the agricultural problems is finding $97 \%$ of the global water in the seas and oceans while the territorial land is about $43 \%$ arid or semi-arid. Presence parts of these areas near the sea are a serious solution for agricultural irrigation, so some wild plants which are tolerant of salinity, namely Halophytes, can be grown. Salicornia (S.) is one of the halophytes plants which contain a high percentage of oil.

Synthetic fertilizers play a significant role in soil and groundwater pollution, causing the crop to be more prone to diseases. Therefore, organic farming becomes an important demand because of healthy food and a clean environment. The essential components of organic farming are biofertilizers. Biofertilizers are the substances that contain living microorganisms and are used in the fields of agriculture to keep the soil rich in all kinds of micro- and macro-nutrients. They are improving soil fertility via nitrogen fixation, phosphate, and potassium solubilization or mineralization, production of antibiotics, and biodegradation of organic matter in the soil (Sheraz Mahdi et al., 2010; Kaushal Kumar et al., 2013; Bhardwaj et al., 2014).

The greenhouse experiment studied the effect of irrigation with diluted seawater $(12.5 \%, 25.0 \%, 37.0 \%$, and $50.0 \%$ ) on the halophytic plants (e.g., Sporobolus, Leplochloa, and Salicornia europa), and found that increasing seawater concentration increased the succulence, $\mathrm{Na} / \mathrm{K}$ ratio, and the content of proline, sodium, pigment, carbohydrates, and protein in the plants at the different cuttings (Yuan et al., 2019; Tawfik et al., 2013).

Tawfik (Tawfik, 2007) pointed out that the nutritional status of the halophytes forages plants concentrated on the quantity of protein, phosphorus, and plant content of produced energy. However, Fang et al. (Yuan et al., 2019) indicated that potassium is an important nutrient and plays an essential role in water relations, osmotic adjustment, stomatal movement, and finally resistance to drought. Nitrogen metabolism is the most important factor that influences plant growth and performance, some studies showed the reduction of nitrate uptake and a decrease in nitrate reductase activity under water stress (Ismail \& Hiroshi, 2012).

The algae are used as a biofertilizer for many plants to overcome the difficult conditions such as high alkaline degree, salinity, and content of calcium. ElSayed et al. (El-Sayed et al., 2015) showed that the application of algae foliar at a rate of $300 \mathrm{~g} / \mathrm{fed}$ achieved the highest values of the fresh and dry weight of the plant. Abd El-Baky et al. (Abd El-Baky et al., 2016) cleared that the algae foliar extracts can improve non-enzymatic and enzymatic antioxidant defense systems in potatoes cultivated under drought stress conditions.

Oil is considered the largest energy source which is playing a central role in human nutrition and to maintain food security (Shahi et al., 2014). The saltwater crops are considered of oil production sources, such as Salicornia spp. which are leafless, succulent, and small-seeded and used as conventional oil crops (Abideen et al., 2015). The physical and chemical analysis of oils showed that their fatty acid composition is similar to other common edible vegetable oils. Salicornia fruticose lipid analysis revealed the presence of 11 fatty acids such as palmitic acid (32.4\%) and linoleic acid (14.16\%) (Radwan et al., 2007). Salicornia bigelovii is very rich in linoleic acid (about 70\%) with a fatty acid profile that is similar to sunflower oil (Gouda \& Elsebaie, 2016). The seed contains about $26-33 \%$ oil (similar to safflower oil), 35\% protein, and salt content of about 3\% (Garcia, 2010).

The most common types of plant oils are waxes, triglycerides, and phospholipids. The molecular structure of triglycerides consists of three fatty acid molecules bonded to one glycerol molecule. Triglycerides are used as an energy source stored mostly in seeds and to a lesser extent within the plant itself. The phospholipid consists of two fatty acids bonded to glycerol with a phosphate functional group (Falasca et al., 2014).

The oil was extracted from the seeds through solvent extraction methods (Narasimha Rao et al., 2015). Elsebaie et al. (Elsebaie et al., 2013) evaluated the methods of oil extraction from glasswort seeds and reported that chloroform and methanol mixture $(2: 1 \mathrm{v}: \mathrm{v})$ gave the maximum amount extracted from seeds (28.59\%). Adewale et al. (Folayan et al., 2019) used the supercritical fluid extraction process (SFE) as a viable alternative to liquid extraction.

The Salicornia oil will be a candidate for biofuel production for containing a small amount of C18:3 (Ruana et al., 2008). The high percentage of polyunsaturated fatty acids $(>40 \%)$ is referring to the nutraceutical and pharmaceutical components in such oil (Kang et al., 2011; Hammami et al., 2018).

The research is focused on the effect of Salicornia bigelovii cultivation under different conditions of irrigation and fertilization on both the percentages and fatty acids composition of the oil. The capability of this oil is to produce biofuel and finally for nutritional, cosmeceutical, and pharmaceutical applications. The characterizations of samples will compare with blank samples that were collected from the desert coastal area of the saline aquatic environment. 


\section{Methods}

From the International Training Centre-Mariut, Alexandria, we obtained of the following:

- The blank samples of S. bigelovii seeds which are collected from the desert coastal area of the saline aquatic environment

- Test samples of S. bigelovii seeds (17 samples) which are subjected to different cultivation conditions of irrigation and fertilization, as shown in Table 1.

- All chemicals were used from the analytical grade

Work steps are as follows:

1. From the desert of the North West Coast areas, the following were collected:

(a) A representative sample of $S$. bigelovii seeds for testing as a blank one

(b) Representative samples of soil, ground well water, and seawater

2. Comparative tests were conducted to identify the most successful cultivation method of S. bigelovii by using either seeds or semi-cuts or hard-cuts or transplants were tested by using some growth regulators (indole butyric acid and gibberellic acid for activate seeds germination and rooting the cuts).

3. Greenhouse experiments using Salicornia transplants were conducted. Saline well water or/ and diluted seawater as a source of irrigation (4

Table 1 Samples key under different combined treatments of fertilization and irrigation

\begin{tabular}{|c|c|c|}
\hline \multicolumn{2}{|l|}{ Treatments } & \multirow{2}{*}{$\begin{array}{l}\text { Sample } \\
\text { No. }\end{array}$} \\
\hline Irrigation & Fertilization & \\
\hline \multirow[t]{4}{*}{$100 \%$ well water } & NPK & 1 \\
\hline & NPK + micro & 2 \\
\hline & Algae & 3 \\
\hline & $\mathrm{NPK}+$ micro + algae & 4 \\
\hline \multirow[t]{4}{*}{$100 \%$ sea water } & NPK & 5 \\
\hline & NPK + micro & 6 \\
\hline & Algae & 7 \\
\hline & NPK + micro + algae & 8 \\
\hline \multirow[t]{4}{*}{$50 \%$ sea water $+50 \%$ well water } & NPK & 9 \\
\hline & NPK + micro & 10 \\
\hline & Algae & 11 \\
\hline & $\mathrm{NPK}+$ micro + algae & 12 \\
\hline \multirow[t]{4}{*}{$25 \%$ sea water $+75 \%$ well water } & NPK & 13 \\
\hline & NPK + micro & 14 \\
\hline & Algae & 15 \\
\hline & $\mathrm{NPK}+$ micro + algae & 16 \\
\hline \multicolumn{2}{|c|}{ Control (without irrigation or fertilization) } & 17 \\
\hline
\end{tabular}

treatments) combined with four fertilization treatments including algae (Amphora) extract (as a source of biofertilizer), NPK, and micronutrients during an integrated and balanced fertilizer program were conducted (Table 1).

4. Whole plants were collected and the seeds were brought out to evaluate oil percentage at different conditions of cultivation and to identify the viability of oil for human consumption and to be used as a biofuel.

5. The blank samples of S. bigelovii seeds were subjected to the following tests:

(a) Determination the humidity percentage

(b) A certain weight $\mathrm{W}_{0}$ of $\mathrm{S}$. bigelovii seeds was dried at $85^{\circ} \mathrm{C}$ until constant weight $W_{1}$. The percentage of humidity will be calculated after cooling.

(c) Oil extraction

(d) The total oil from the dried seeds after grinding was extracted using different solvents of hexane, hexane to isopropanol mixture $(3: 2 \mathrm{v} / \mathrm{v})$, and ethanol through different techniques, at ratio 1:6 wt./v of dry biomass to solvent, as follows:

(e) Shaker (Elsebaie et al., 2013) Mixing of $10 \mathrm{~g}$ of ground seeds with solvent in a conical flask was done. The mixture was subject to agitation, at ambient temperature for $24 \mathrm{~h}$ using a shaker (Model3060, ORBITAL SHAK $\mathrm{ER})$, at $150 \mathrm{rpm}$. In the end, the reaction mixture was filtrated and the solvent will be evaporated by using a rotary vacuum evaporator.

(f) Conventional method (Basily et al., 2018a)

(g) Ground seeds (10 g) with organic solvent were placed in a flask. The suspensions were continuously stirred using a magnetic stirrer at constant temperature $(655 \mathrm{C})$ for $2 \mathrm{~h}$ with reflux. After extraction time and filtration, the oil will be separated from the solvent using a rotary evaporator.

(h) Ultrasonic probe technique (Basily et al., 2018a)

(i) The same steps as in conventional method except that the suspension will be subjected to ultrasonic generator probe Model Sollics Vibra Cell V500 at room temperature, for $15 \mathrm{~min}$. After extraction and filtration, the oil will be separated from the solvent using a rotary vacuum evaporator.

(j) The oil samples after all the extraction processes are transferred to sealed glass vials and stored at $5{ }^{\circ} \mathrm{C}$ for further analysis.

(k) The samples of $S$. bigelovii seeds which are subject to different treatments of irrigation and fertilization as shown in Table 1 will be dried 
and ground to prepare for the oil extraction process by ultrasonic generator probe Model Sollics Vibra Cell V500 at room temperature, for 15 min using a solvent system of ethanol. After extraction and filtration, the oil will be separated from the solvent using a rotary vacuum evaporator.

6. Gas chromatography analysis of extracted oil

(a) For all extraction processes, the fatty acids profiles for oil samples were determined using chromatography (GC) provided with a split automatic injector and silica capillary column DB-5 (length, $60 \mathrm{~m}$; ID, $0.32 \mathrm{~mm}$ ). Helium is used as a carrier gas at a flow rate of $1 \mathrm{~mL} / \mathrm{min}$. The column was held at $150^{\circ} \mathrm{C}$ for $1 \mathrm{~min}$ and ramped to $240{ }^{\circ} \mathrm{C}$, at a rate of $30^{\circ} \mathrm{C} / \mathrm{min}$, and held at $240^{\circ} \mathrm{C}$, for $30 \mathrm{~min}$. Standards are used to give rise to well-individualized peaks that allow the identification of the fatty acid composition.

(b) Cetane number of the produced oil can be calculated from the fatty acid profiles according to the following equation (Clements 1996; Hawash and AboElenin, 2015):

$\mathrm{CM}=\Sigma \mathrm{XME}($ wt.\%).CNME

(c) where $\mathrm{CN}$ is the cetane number of biodiesel, XME is the weight percentage of each methyl ester, and CNME is a cetane number of individual methyl ester

7. Extraction of phenolic compounds

(a) Four grams of de-oiled biomass was suspended in $20 \mathrm{ml}$ of $80 \%$ ethanol, homogenized for $3 \mathrm{~min}$ at $4{ }^{\circ} \mathrm{C}$ to disrupt cells. The homogenate was centrifuged at $2000 \mathrm{rpm}$ for $15 \mathrm{~min}$ at $4{ }^{\circ} \mathrm{C}$.

(b) The resulting supernatant was centrifuged again at $2000 \mathrm{rpm}$ for $10 \mathrm{~min}$. the residue was repeatedly extracted with the same solvent until they were colorless. Then, the supernatant was filtered through Millipore filters. The filtrate was evaporated to dryness to give a crude ethanolic extract (enriched in phenolic compounds) and immediately analyzed (Sarojini et al., 2013; Basily et al., 2018b).

(c) Total phenols extracts were determined in triplicate by the Folin-Ciocalteu reagent using gallic acid as a standard (Singleton \& Rossi, 1965; Anandjiwala, 2007).

8. Extraction of flavonoids compounds (Baviskar \& Khandelwal, 2015)

(a) One gram of de-oiled biomass was crushed in motor, added $5 \mathrm{ml}$ of distilled water, centrifuged at $1000 \mathrm{rpm}$ for $15 \mathrm{~min}$, and incubated at $4{ }^{\circ} \mathrm{C}$ for $20 \mathrm{~min}$. Then, it was transferred to the water bath adjusted at $100{ }^{\circ} \mathrm{C}$ for $20 \mathrm{~min}$. The supernatant was filtrated through filter paper No. 1 the filtrate was adjusted to $25 \mathrm{ml}$ with $95 \%$ methanol solution and incubated at room temperature for $48 \mathrm{~h}$ for the determination of flavonoid content. Total flavonoid was measured by a colorimetric assay according to Kim et al. (Dae-Ok et al., 2003) with some modifications (Khaleghnezhad et al., 2019). Flavonoid content (FC) was expressed as mg Rutin equivalents per gram of dried biomass (mg RE $\mathrm{g}^{-1}$ ) (Massoumeh et al., 2014).All samples were analyzed three times.

\section{Results}

\section{Humidity percentage}

The percentage of water in the dried seeds at $85^{\circ} \mathrm{C}$ until a constant weight had recorded an average of $8 \%$ dry weight.

\section{Oil content of blank sample}

The yield percentage of oil extracted from dry biomass of blank samples of $S$. bigelovii seeds by different methods (shaker, conventional, and ultrasonic probe) using different organic solvents are reported in Fig. 1.

The oil percentage obtained by using the ultrasonic probe is more than that by the conventional method which recorded a percentage of oil more than that of the shaker process. The ethanol in all extraction techniques produced a maximum yield of oil. Hexane-isopropanol recovered an oil percentage higher than hexane.

\section{Fatty acid profile of blank sample}

Gas chromatography analysis of the fatty acids composition of blank samples oils, which are extracted by three methods (shaker, conventional, and ultrasonic probe) using ethanol solvent represented in Table 2.

The GC analysis showed eleven fatty acids distinctly. Six were saturated and five unsaturated. The palmitic (C16:0) was the dominant saturated fatty acids (18.6$19.5 \%)$, while linoleic- $\omega 6$ acid $(18: 2)$ was the major unsaturated fatty acid (34.3-35.3\%), oleic acid (18:1) as mono-unsaturated fatty acid recorded $16-17.5 \%$ of total fatty acids. The unsaturated FA (USFA) was almost twice saturated FA (SFA). 


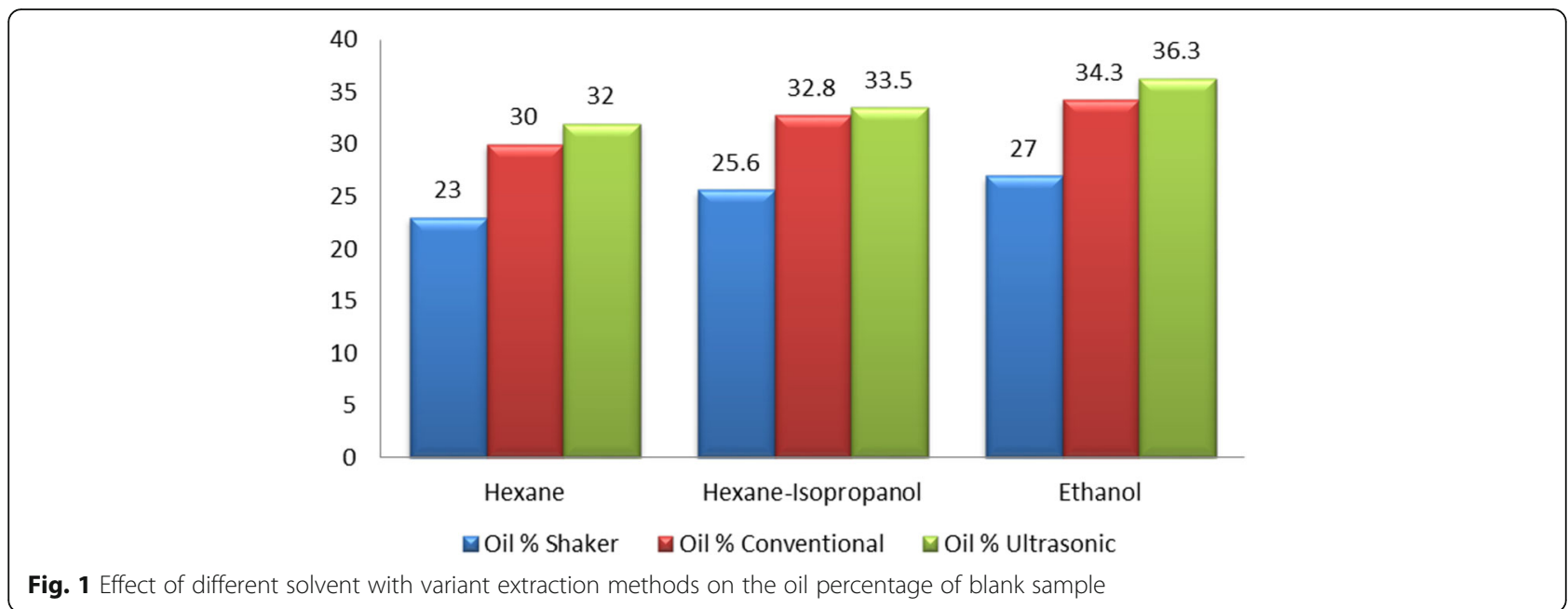

\section{Effect of different cultivation treatments on Oil yield}

The cultivation of S. bigelovii plant under variant mixed treatments of irrigation and fertilizing was affected on its oil content as clearing in Table 3.

The recovered oil, by ethanol with an ultrasonic probe, from the blank sample (B) which was a representative sample from the desert of the North West Coast, was $36.3 \%$. However, the highest percentage of oil was 35\% obtained from sample No. 16, which was subjected to $75 \%$ well water for irrigation and fertilized with a combination of NPK + micro + algae. The control sample No. 17 was grown under the same environmental conditions of cultivation as the other samples (1-16),

Table 2 Fatty acids profile of blank samples oil extracted by different methods using ethanol

\begin{tabular}{llll}
\hline Fatty & F.A. \% of & & \\
\cline { 2 - 4 } Acids & Shaker & Conventional & Ultrasonic \\
\hline C12 & 3.5 & 3.0 & 4.2 \\
C16 & 18.6 & 19 & 19.5 \\
C17 & 4.0 & 4.3 & 3.5 \\
C18 & 1.5 & 2.0 & 2.5 \\
C20 & 5.5 & 6.0 & 4.5 \\
C24 & 1,2 & 0.5 & 1.1 \\
C18:1 $\omega-9$ & 16.0 & 17.1 & 17.5 \\
C20:1 & 2.2 & 1.2 & 0.8 \\
C18:2 $\omega-6$ & 34.9 & 36.0 & 36.5 \\
C18:3 $\omega-3$ & 5.2 & 5.4 & 5.5 \\
C22:2 $\omega-3$ & 5.0 & 4.9 & 4.4 \\
SFA & 34.3 & 34.8 & 35.3 \\
USFA & 63.3 & 64.6 & 64.7 \\
MUSFA & 18.2 & 18.3 & 18.3 \\
PUFA & 45.1 & 46.3 & 46.4 \\
\hline
\end{tabular}

excluding irrigation and fertilization. It produced an acceptable amount of oil (25\%), but less than the oil \% in the blank sample (B).

\section{Fatty acid composition}

The oil compositions of different cultivation treatments samples (1-17) were determined by GC analysis, as shown in Table 4.

The different combined treatments of fertilization and irrigation of $S$. bigelovii have changed the fatty acid

Table 3 Total oil \% of S. bigelovii seeds cultivated under different combined treatments

\begin{tabular}{|c|c|c|c|}
\hline \multicolumn{2}{|l|}{ Treatments } & \multirow{2}{*}{$\begin{array}{l}\text { Sample } \\
\text { No. }\end{array}$} & \multirow{2}{*}{$\begin{array}{l}\text { Oil } \\
\%\end{array}$} \\
\hline Irrigation & Fertilization & & \\
\hline \multirow[t]{4}{*}{$100 \%$ well water } & NPK & 1 & 30 \\
\hline & NPK + micro & 2 & 26 \\
\hline & Algae & 3 & 20 \\
\hline & $\mathrm{NPK}+$ micro + algae & 4 & 33 \\
\hline \multirow[t]{4}{*}{$100 \%$ sea water } & NPK & 5 & 21 \\
\hline & NPK + micro & 6 & 22 \\
\hline & Algae & 7 & 21.2 \\
\hline & $\mathrm{NPK}+$ micro + algae & 8 & 25 \\
\hline \multirow[t]{4}{*}{$50 \%$ sea water $+50 \%$ well water } & NPK & 9 & 26 \\
\hline & NPK + micro & 10 & 25,5 \\
\hline & Algae & 11 & 20.5 \\
\hline & $\mathrm{NPK}+$ micro + algae & 12 & 33 \\
\hline \multirow[t]{4}{*}{$25 \%$ sea water $+75 \%$ well water } & NPK & 13 & 19 \\
\hline & NPK + micro & 14 & 25 \\
\hline & Algae & 15 & 22 \\
\hline & $\mathrm{NPK}+$ micro + algae & 16 & 35 \\
\hline \multicolumn{2}{|c|}{ Control without irrigation and fertilization } & 17 & 25 \\
\hline \multicolumn{2}{|l|}{ Blank } & B & 36.3 \\
\hline
\end{tabular}


Table 4 The fatty acid profile and cetane No. of oil in samples cultivated under different treatments

\begin{tabular}{|c|c|c|c|c|c|c|c|c|c|c|c|c|c|c|c|c|c|}
\hline \multirow[t]{2}{*}{ F.A } & \multicolumn{17}{|c|}{ Sample No. } \\
\hline & 1 & 2 & 3 & 4 & 5 & 6 & 7 & 8 & 9 & 10 & 11 & 12 & 13 & 14 & 15 & 16 & 17 \\
\hline $\mathrm{C} 12$ & 1 & 6 & 2.9 & 5.1 & - & 12 & 10 & 7 & 3.5 & - & 2.9 & 2 & 8 & 4 & 4.9 & 1.6 & - \\
\hline $\mathrm{C} 14$ & 15 & 1 & 8.7 & 5.4 & 3 & 15 & 13 & 3 & 3.7 & 1.6 & 10 & 4 & 20.5 & 2 & 5.4 & 1.6 & - \\
\hline $\mathrm{C} 16$ & 24 & 27 & 46 & 44 & 40 & 48 & 41 & 57 & 48 & 28 & 38 & 43 & 44.5 & 35 & 29 & 24 & 31.3 \\
\hline $\mathrm{C} 18$ & 10 & 21 & 16 & 17 & 18 & 10 & 10 & 18 & 26 & 20 & 14 & 19 & 16.4 & 20 & 16 & 19 & 22.2 \\
\hline C18-1 $\omega-9$ & 8 & 36 & 2.8 & 19 & 22 & 10 & 4 & 9 & 7.8 & 40 & 31 & 27 & 2.7 & 32 & 34 & 40 & 30.3 \\
\hline C18-2 $\omega-6$ & 30 & 3 & 7.3 & 10 & 10 & 3 & 11 & 3.4 & 7.8 & 7 & 4 & 3.2 & 5.3 & 5 & 7.7 & 10 & 12.2 \\
\hline C18-3 $\omega-3$ & 4 & 1 & 1.3 & 0 & 1.3 & 2 & 11 & 3 & 2.9 & 4 & - & 1.4 & 2.5 & 2 & 2.5 & 2.1 & 3.2 \\
\hline S.F.A. & 51 & 55 & 73 & 71 & 60.7 & 58 & 74 & 84 & 81 & 49 & 64.9 & 68 & 89.4 & 61 & 56 & 46 & 54.2 \\
\hline US.F.A. & 42 & 41 & 11 & 29 & 33.8 & 15 & 26 & 15 & 19 & 51 & 35 & 31.6 & 10.5 & 39 & 44 & 52 & 45.7 \\
\hline MUS.F.A. & 8 & 36 & 2.8 & 19 & 22.3 & 10 & 4 & 9 & 7.8 & 40 & 31 & 27 & 2.7 & 32 & 34 & 40 & 30.3 \\
\hline PUFA & 35 & 5 & 8.6 & 10 & 11.5 & 5 & 22 & 6.4 & 11 & 11 & 4 & 4.6 & 7.8 & 7 & 10 & 12 & 15.5 \\
\hline T.F.A & 93 & 96 & 85 & 99 & 94.5 & 99 & 100 & 100 & 100 & 100 & 99.9 & 99.6 & 99.9 & 100 & 100 & 98 & 99.9 \\
\hline MUS./ S.F. & 0 & 1 & 0 & 0.3 & 0.4 & 0.1 & 0.1 & 0.3 & 0.1 & 0.8 & 0.5 & 0.4 & 0.03 & 0.5 & 0.6 & 0.8 & 0.6 \\
\hline PUS./S.F.A. & 1 & 0 & 0.1 & 0.2 & 0.2 & 0.1 & 0.3 & 0.1 & 0.1 & 0.2 & 0.1 & 0.1 & 0.1 & 0.1 & 0.2 & 0.3 & 0.3 \\
\hline PUS/MUS. & 5 & 0 & 3.1 & 0.5 & 0.5 & 0.5 & 5 & 0.5 & 1.4 & 0.3 & 0.1 & 0.2 & 2.8 & 0.2 & 0.3 & 0.3 & 0.5 \\
\hline PU.+MU/SF & 1 & 1 & 0.2 & 0.4 & 0.6 & 0.2 & 0.3 & 0.4 & 0.2 & 1 & 0.5 & 0.5 & 0.1 & 0.6 & 0.8 & 1.1 & 0.8 \\
\hline Cetane No. & 55 & 66 & 61 & 70 & 64.9 & 70 & 62 & 69 & 71 & 66 & 61.2 & 70.4 & 66.8 & 68 & 66 & 64 & 66.3 \\
\hline
\end{tabular}

S.F.A. saturated fatty acid, US.F.A. unsaturated fatty acid, M US.F.A. mono-unsaturated F.A., PUFA polyunsaturated fatty acid, T.F.A. total fatty acid

profiles of all samples, where the saturated FA (SFA) was more than the unsaturated FA (USFA), except two samples No. 10 and 16 where the USFA percentage is higher than SFA, by $2-6 \%$.

The most abundant saturated fatty acids were palmitic acid (C16:0) and stearic acid (C18:0). Oleic acid (C18:1) and linoleic acid (C18:2) were the most unsaturated fatty acid present.

\section{Nutrition activity}

Fatty acids Generally, the ratio of polyunsaturated fatty acid (PUFA) to saturated fatty acid (SFA) is used to evaluate the nutritional value of oil (Choi et al., 2014; López-Yerena et al., 2018). The effects of MUFA and PUFA+MUFA/SFA on the plasma and liver lipid concentrations in rats were examined by Chang and Huang (López-Yerena et al., 2018). They concluded that MUFA/SFA must be $<1$, PUFA/SFA $<2$, and PUFA/ MUFA $>2$ and PUFA+MUFA/SFA must not exceed than 2, for lowering the effects of triacylglycerol and cholesterol on the plasma and liver lipid concentrations.

The ratio of polyunsaturated fatty acid to saturated fatty acid for the blank sample was in agreement with Chang and Huang, where

MUFA/SFA $=0.5$, PUFA $/$ SFA $=1.3$, PUFA $/$ MUFA $=$ 2.5, and PUFA+MUFA/SFA = 1.8.

The GC analysis of oil samples (Table 3), recorded that, all of them are not rich in PUFA.
The ratios of PUFA/SFA for nutrition value were not revealed for most samples.

Total phenolic and flavonoid content The total polyphenolic content of investigated samples 1-17 according to the Folin method differed from one to another between 2.13 and $3.66 \mathrm{mg}$ Gallic/1 g dry weights of deoiled biomass, as shown in Fig. 2. The colorimetric determination of total flavonoid content in the samples recorded a variation from 1.28 to $2.44 \mathrm{mg} / 1 \mathrm{~g}$ dry weight in flavonoid content. The samples with higher oil \% recorded low phenolic and flavonoid content, whereas the phenolic and flavonoid content in the blank sample was higher value, 4.5 and $2.9 \mathrm{mg} / 1 \mathrm{~g}$, respectively.

\section{Discussion}

\section{Oil content of blank sample}

The results show that ethanol has higher extraction efficiency than the other used solvents. This is for the fact that the efficiency of oil extraction is mostly dependent on the solvent polarity (Basily et al., 2018a).

The polar solvents can open the wall of cells and thus allow more extraction of the cell contents (Tir et al., 2012), so it is the most promising solvent for oil extraction. The ethanol and isopropanol as polar solvents of short-chain alcohols are used in several studies as alternative solvents for extraction because they are safer (Rodrigues et al., 2010; Russin et al., 2010). 


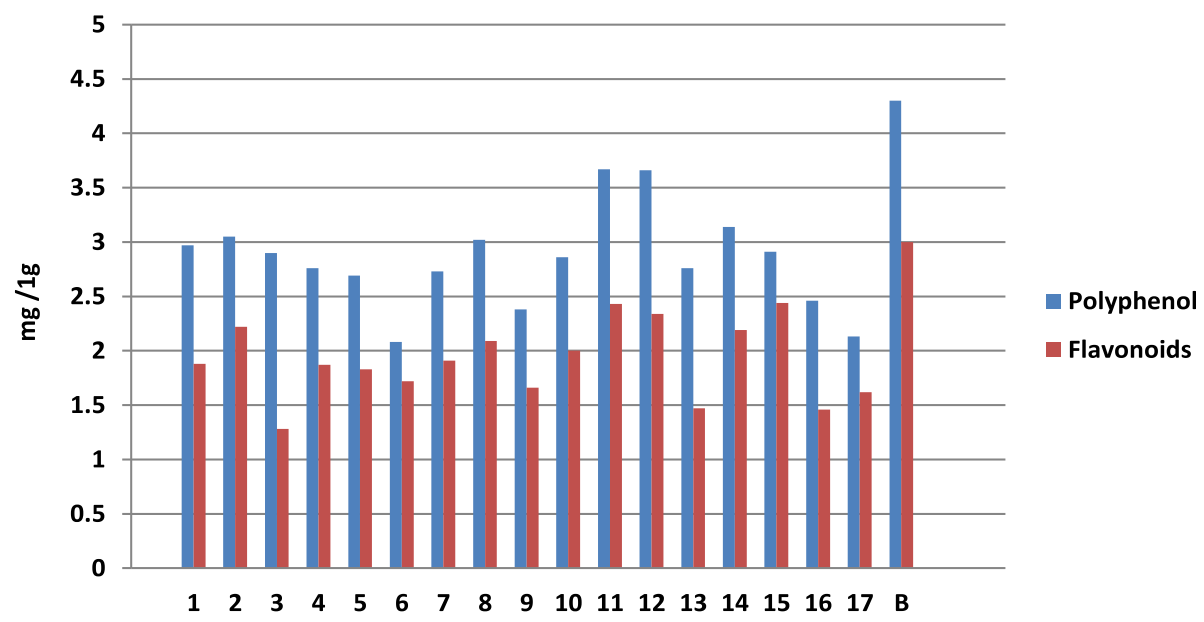

Fig. 2 The polyphenolic and flavonoids content in samples, 1-17 and blank (B)

The ultrasonic probe systems recorded maximum oil $\%$ with all solvents used for extraction process. The performance of ultrasonic technique is based on an electromagnetic transducer (i.e., converting mechanical energy or electrical one to big frequency sound) as an ultrasound power, commonly operating at a frequency of 20 $\mathrm{kHz}$, and the ultrasonic probe energy is introducing directly into the extraction vessel not transfer through the liquid medium to the cells (Basily et al., 2018a).

\section{Fatty acid profile of blank sample}

There are slight differences in the fatty acid composition of the oil extracted either by different methods or with various organic solvents. This means that the extraction method and the solvent are affecting in the oil yield percentage, not in the oil composition. The result is in agreement with previous studies (Basily et al., 2018a).

\section{Effect of different cultivation treatments on Oil yield}

The environmental conditions of cultivation are primary factors in the oil yield percentage. Previous researches (Yuan et al., 2019; Tawfik et al., 2013; Tawfik, 2007) studied the effect of different cultivation treatments on the productivity of the halophyte plants. From the percentages of oil in our study, it can be concluded that the well water and NPK + micro + algae have a significant effect to increase the percentage of oil recovery from the seeds. Samples 4, 8, 12, and 16 were cultivated under the same treatments of fertilization of micronutrients, NPK, and biofertilizer of algal extract and different irrigation system at well water percentage of $100,0,50$, and $75 \%$. The lowest oil \% was recorded from sample 8 due to the absence of well water in its irrigation system, and increases with the increasing percentage of well water to reach a higher value at sample 16 with inserting $25 \%$ seawater. This is in agreement with other studies (Bhardwaj et al., 2014; Tawfik et al., 2013), where the moderate salinity and biofertilizer improve the productivity of halophyte and its contents of protein and carbohydrate. The other combined treatments of fertilization and irrigation of $S$. bigelovii recorded lower oil percentages.

\section{Fatty acid composition}

In previous research (Knothe, 2012), palmitic, stearic, oleic, and linoleic acids were recognized as the most common fatty acids that were suitable for biodiesel production. In particular, oils with oleic acid (C18-1) content have been reported to have a feasible balance of fuel properties (Gopinath et al., 2015). That agrees with our results as clear in a Table 4, the calculated cetane number of FA components higher than 50 for all samples. Overall, the oil of cultivated samples is reasonable for biodiesel production with good quality (Gopinath et al., 2015). The stability of the oil is better than the other commercial oils because of the small amount of linolenic acid C18:3 (5.2-5.5\%) (Gopinath et al., 2015).

Comparing with the blank sample (B) found that it contains FAs with a carbon chain of more than 18 as C20, C20-1 C22-2, and C24. The percentage of palmitic A. and stearic A. is very low, $19.5 \%$ and $2.5 \%$, respectively. Its cetane No. is too small (29.6). As a result, the oil of this sample (B) is not promising enough for biofuel production.

\section{Nutrition activity}

Fatty acids The unsaturated fatty acids of the blank sample were recorded $>63 \%$ of the total FAs. Such FAs composition has an important role in cosmetology and medical applications (Minzangi et al., 2011; Torri et al., 
2019). The free FAs can be generated in the skin as a result of triglycerides decomposition by bacteria. The destruction of the epidermal protective layer and loss of skin water leads the epidermis to produce more lipids in the lamellar granules of the stratum granulose. The regeneration of the lipids decreases with aging, so the oilcontaining FAs of omega- 6 series increase the lipid's reproduction in the lamellar granules (Zare et al., 2019). The blank sample oil was rich in polyunsaturated fatty acids, especially, oleic acid (17.5\%) and linoleic acid (36.5\%), which have a medical effect. Naturally, the linoleic C18:2 is a component of sebum, and decreasing its content assists to block skin pores leading to the formation of eczemas and comedos. So the linoleic can be used for solving the problems of skin care and skin richness (Zielińska \& Nowak, 2014).

Total phenolic and flavonoid content The total phenolic concentrations of investigated samples based on the Folin method were varied from sample to another one (Fig. 2). This agrees with previous studies that demonstrated that culture parameters and the type of plant are affected in the concentration and composition of phenolic compounds of biomass (Safafar et al., 2015). Phenolic compounds are considered to be biologically active components with various health beneficial properties (Zhao et al., 2014).

The colorimetric determination of flavonoid content clarifies a variation in flavonoid content which may be due to the difference in physicochemical parameters of cultivation. Flavonoids are secondary metabolites and have the capacity to act as strong antioxidants capable to scavenge free radicals which are harmful to the human body and food products (Shashank \& Abhay, 2013).

With the increasing demand for natural products in pharmaceuticals, nutraceuticals, and cosmetic industries, flavonoids and phenolic are gaining vital importance with their multiple activities as antioxidants by inhibition of reactive oxygen species (ROS) generation and direct or indirect scavenging of free radicals. Recently, natural antioxidants discovered in plants have attracted some interest as anti-microbial, anti-cancer, and anti-diabetic. They have the capacity to improve food quality and stability (Esmaeili et al., 2015).

\section{Conclusion}

The different combined treatments of fertilization and irrigation of S. bigelovii changed the fatty acid profiles of all samples than the blank one, where the saturated FA became more than the unsaturated FA. Except for two samples 10 and 16, there is no significant difference between the SFA and USFA percentages. Such oil is being more reasonable for biodiesel production. The most abundant saturated fatty acids were palmitic acid (C16:0) and stearic acid (C18:0). Oleic acid (C18:1) and linoleic acid (C18:2) were the most abundant unsaturated fatty acid. In palmitic, stearic, oleic, and linoleic acids were recognized as the most common fatty acids for biodiesel. In particular, oils with oleic acid content have been reported to have a feasible balance of fuel properties that agrees with our results. The higher cetane number than 50 for all samples is referring to this oil has power for biodiesel production with good ignition properties. The nutrition activity of the blank sample was higher than the recultivated samples. The omega series acids $\omega-9$ (oleic), $\omega-6$ (linoleic), and $\omega-3$ ( $\alpha$-linolenic) have wide applications in cosmetic industries as thickening agents, water-binding agents, and antioxidants in facial and skin care products. Phenolic compounds have an important role in human health as radical scavengers. Flavonoids are secondary metabolites with multiple activities as anti-microbial, anti-cancer, and anti-diabetic.

\section{Abbreviations}

FAO: Food and Agriculture Organization of the United Nations;

SFE: Supercritical fluid extraction process; S. bigelovii: Salicornia bigelovii; $\mathrm{CN}$ : Cetane number of biodiesels; ME: Weight percentage of methyl ester; CNME: Cetane number of individual methyl ester; FC: Flavonoid content; S.F.A.: Saturated fatty acid; US.F.A.: Unsaturated fatty acid; M US.F.A.: Monounsaturated F.A.; T.F.A.: Total fatty acid; PUFA: Polyunsaturated fatty acid

\section{Acknowledgements \\ This paper represents a part of the activities of "Development the production and quality of Salicornia plants on different salty sources of water in the North West Coast of Egypt" project, principal investigator Prof. Dr. A.I. Rezk. The project was supported by the National Research Centre (NRC), Egypt.}

\section{Authors' contributions}

R. E and S.A.: Experimental part and writing the research paper. O.A. and A.B.: Preparing experiments work plan. A.l.: Reviewing and contributing in writing the research paper. "All authors have read and approved the manuscript.".

\section{Funding}

The authors declare that they have no known competing financial interests or personal relationships that could have appeared to influence the work reported in this paper.

Availability of data and materials

Data sharing is not applicable to this article as no datasets were generated or analyzed during the current study.

Ethics approval and consent to participate

There is no committee of approval.

Consent for publication

"Not applicable"

\section{Competing interests}

The authors declare that they have no competing interests.

\section{Author details}

${ }^{1}$ Chemical Engineering and Pilot Plant National Research Centre, Giza, Egypt.

${ }^{2}$ Fertilization Technology National Research Centre, Giza, Egypt. ${ }^{3}$ Plant

Nutrition Departments, National Research Centre, Giza, Egypt. 
Received: 3 June 2020 Accepted: 27 July 2020

\section{Published online: 12 August 2020}

\section{References}

Abd El-Baky, H.H; Nofal, O.N. and El-Baroty, G.S.(2016): Enhancement of antioxidant enzymes activities, drought stress tolerances and quality of potato plants as response to algal foliar application, recent Patent Food Nutrition Agric. ,8:1-8

Abideen Z, Qasim M, Rizvi RF, Gul B, Ansari R, Khan MA (2015) Oilseed halophytes: a potential source of biodiesel using saline degraded lands. Biofuels 6:241-248

Anandjiwala S (2007) Antioxidant activity of stem bark of Thespepsia populnea. J Nat Remedies 7:135-141

Basily HS, Nassar MM, El Diwani Gl, Abo El-Enin SA (2018a) Extraction of algal lipid as a natural cosmetic component. Egyptian Pharmaceut J 17:1

Basily HS, Nassar MM, El Diwani Gl, Abo El-Enin SA (2018b) Exploration of using the algal bioactive compounds for cosmeceuticals and pharmaceutical applications. Egyptian Pharmaceut J 17:2

Baviskar JW, Khandelwal SR (2015) Extraction, detection and identification of flavonoids from microalgae: an emerging secondary metabolite. Int. J. Curr. Microbiol. App. Sci (2):110-117

Bhardwaj D, Ansari MW, Sahoo RK, Tuteja N (2014) Biofertilizers function as key player in sustainable agriculture by improving soil fertility, plant tolerance and crop productivity. Microb Cell Factories 13:66

Choi D, Lim G-S, Piao YL, Choi O-Y, Cho K-A, Park C-B, Chang Y-C, Lee Y-ISM-K, Cho $H$ (2014) Characterization, stability, and antioxidant activity of Salicornia herbaciea seed oil. Korean J Chem Eng 31(12):2221-2228

Clements, L.D., (1996), Blending rules for formulating biodiesel fuel. Liquid fuel industrial products from renewable resources. In: Proceedings of the Liquid Fuel Conference, 3rd, Nashville, September 15-17c44-53.

Dae-Ok K, Chun OK, Kim YJ, Moon H-Y, Lee CY (2003) Quantification of polyphenolics and their antioxidant capacity in fresh plums. J Agric Food Chem 51:6509-6515 6509

El-Sayed SSA, Hellal FA, Nofal OA, El-Karamany MF, Bakry AB (2015) Influenced of algal extracts on yield and chemical composition of Moringa and Alfalfa grown under drought condition. Int J Environ 4:151-157

Elsebaie EM, Elsanat SY, Gouda MS, Elnemr KM (2013) Oil and fatty acids composition in glasswort (Salicornia fruticosa) seeds. IOSR J Appl Chem 4(5):06-09

Esmaeili AK, Taha RM, Mohaje S, Banisalam (2015) Antioxidant activity and total phenolic and flavonoid content of various solvent extracts from in vivo and in vitro grown Trifolium pratense L. (red clover). Biomed Res Int 2015(643285):11

Falasca SL, Ulberich A, Acevedo A (2014) Identification of Argentinian saline drylands suitable for growing Salicornia bigelovii for bioenergy. Int J Hydrog Energy 39(16):8682-8689. https://doi.org/10.1016/j.ijhydene.2013.12.061

Fan Y, Wang C, Nan Z (2014) Comparative evaluation of crop water use efficiency, economic analysis and net household profit simulation in arid Northwest China. Agric Water Manag 146:335-345

Folayan AJ, Anawe PA, Ayeni AO (2019) Synthesis and characterization of Salicornia bigelovii and Salicornia brachiata halophytic plants oil extracted by supercritical CO2 modified with ethanol for biodiesel production via enzymatic transesterification reaction using immobilized Candida antarctica lipase catalyst in tert-butyl alcohol (TBA) solvent. Cogent Eng 6:1625847

Garcia, R. M. (2010). Physiological studies of the halophyte Salicornia bigelovii: a potential food and biofuel crop for integrated aquaculture- agriculture systems. The University of Arizona.

García-Caparrós P, Llanderal A, El-Tarawy A, Maksimovic I, Lao MT (2018) Crop and irrigation management systems under greenhouse condition. Water 10:62

Gopinath A, Sairam K, Velraj R, Kumaresan G (2015) Effects of the properties and the structural configurations of fatty acid methyl esters on the properties of biodiesel fuel: a review. J Automobile Engineering 229(3):357-390

Gouda MS, Elsebaie EM (2016) Glasswort (Salicornia spp) as a source of bioactive compounds and its health benefits: a review. Alex J Fd Sci Technol 13(1):1-7

Hammami N, Gara AB, Bargougui K et al (2018) Improved in vitro antioxidant and antimicrobial capacities of polysaccharides isolated from Salicornia arabica. Int J Biol Macromol 120:2123-2130

Hawash S, AboElenin SA, ElDiwani G, (2015), Direct conversion of dry algae to biodiesel under supercritical methanolysis, Int J Agric Innov Res, Volume 2 , Issue 6, 2319-1473.
Ismail, M.D and Hiroshi H (2012): Water stress. Free online editions of Intech Books and Journals can be found at www.intechopen.com

Kang S D, Kim B. H, Lee M. R, Kim M. H, Chiang and Hong, JG (2011), Food Sci Biotechnol., 20, 115

Khaleghnezhad V, Yousefi AR, Tavakoli A, Farajmand B (2019) Interactive effects of abscisic acid and temperature on rosmarinic acid, total phenolic compounds, anthocyanin, carotenoid and flavonoid content of dragonhead (Dracocephalum moldavicaL.). Sci Hortic 25010:302-309

Knothe G (2012) Fuel properties of highly polyunsaturated fatty acid methyl esters. Prediction of fuel properties of algal biodiesel. Energy Fuel 26 $5265-5273$

Koyro HW, Khan MA, Lieth H (2011) Halophytic crops: a resource for the future to reduce the water crisis. Emir J Food Agric 23(1):01-16

Kumar K, Shukla UN, Kumar D, Pant AK and Prasad S.K, (2013), Bio-fertilizers for organic agriculture fertilizers, 1(4):91-96.

López-Yerena A et al (2018) Effect of genotype and crop year on the nutritional value of walnut virgin oil and defatted flour. Sci Total Environ 6341:10921099

Massoumeh F, Ramazan-Ali K, Seyed M, Foroogh N (2014) Antioxidant activity, total phenolics and flavonoid contents of some edible green seaweeds from Northern Coasts of the Persian Gulf. Iran J Pharm Res 1:163-170

Minzangi K, Kaaya AN, Kansiime F, Tabuti JRS, Samvura B, Grahl-Nielsen O (2011) Fatty acid composition of seed oils from selected wild plants of Kahuzi Biega National Park and surrounding Democratic Republic of Congo. Afr J Food Sci 5(4):219-226

Radwan HM, Nazif NM, Abou-Setta LM (2007) Phytochemical investigation of Salicornia fruticosa (L.) and their biological activity. Res J Med Med Sci 2:72-78

Rao GN, Murty PP, Kumar MM (2015) Seeds of Salicornia brachiata as a source of edible oil. Indian J Appl Res 5(8)

Rodrigues CEC, Aracava KK, Abreu FN (2010) Thermodynamic and statistical analysis of soybean oil extraction process using renewable solvent. Int J Food Sci Technol 45:2407-2415

Ruana CJ, Lia H, Guob YQ, Inb P, Gallagherc JL, Seliskarc DM, Luttsd S, Mahye GKV (2008) An agroecoengineering halophytic species for alternative agricultural production in China's east coast: ecological adaptation and benefts, seed yield, oil content, fatty acid and biodiesel properties. Ecol Eng 32(4):320-328

Russin TA, Boye Jl, Arcand Y, Rajamohamed SH (2010) Alternative techniques for defatting soy: a practical review. Food Bioprocess Technol 4:2200-2223

Safafar H, Van Wagenen J, Møller P, Jacobsen C (2015) Carotenoids, phenolic compounds and tocopherols contribute to the antioxidative properties of some microalgae species grown on industrial wastewater. Mar Drugs 13: 7339-7356. https://doi.org/10.3390/md13127069

Sarojini Y, Sujatha B, Lakshminarayana K (2013) Total phenol content and antioxidant activities of ethanolic extracts of two marine brown macroalgae. Int J Curr Sci 8(E):43-49 ISSN 2250-1770

Shahi M, Esfahan EZ, Saaghari M, Jaimand K (2014) Quantitative and qualitative investigation on Salicornia herbacea oil seed as a source of edible oil. Eur $J$ Exp Biol 4(3):620-624

Shashank K, Abhay K (2013) Chemistry and biological activities of flavonoids: an overview. Sci World J 1:1-16

Sheraz Mahdi S, Hassan Gl, Samoon SA, Rather HA, Dar SA, Zehra B (2010) Biofertilizers in organic agriculture. J Phytol 2(10):42-54

Singleton VL, Rossi JA (1965) Colorimetry of total phenolics with phosphomolybdic phosphotungstic acid reagents. Am J Enol Vitic 16: 144-153

Tawfik MM (2007) The possibilities of using some halophytic plants as green forage (Review article). Field Crop Research department, National Research Centre, pp 1-27

Tawfik MM, Thalooth AT, Nabila MZ, Hassanein MS, Amany AB, Amal GA (2013) Sustainable production of Kochia indica grown in saline habitat. Enviro Treat Tech 1(1):56-61

Tir R, Dutta PC, Badjah-Hadj-Ahmed AY (2012) Effect of the extraction solvent polarity on the sesame seeds oil composition. Eur J Lipid Sci Technol 114: $1427-1438$

Torri L, Bondioli P, Folegatti L, Rovellini P, Piochi M, Morini G (2019) Development of Perilla seed oil and extra virgin olive oil blends for nutritional, oxidative stability and consumer acceptance improvements. Food Chem 28615:584591

Yuan F, Xu Y Leng B, Wang B (2019) Beneficial effects of salt on halophyte growth: morphology, cells, and genes. Open Life Sci 14:191-200 
Zare T, Rupasinghe TW, Boughton BA, Roessner U (2019) The changes in the release level of polyunsaturated fatty acids ( $\omega-3$ and $\omega-6)$ and lipids in the untreated and water-soaked chia seed. Food Res Int 126:108665

Zhao HX, Zhang HS, Yang SF (2014) Phenolic compounds and its antioxidant activities in ethanolic extracts from seven cultivars of Chinese jujube. Food Sci Human Wellness 3:183-190

Zielińska A, Nowak I (2014) Fatty acids in vegetable oils and their importance in cosmetic industry. Chemik 68(2):103-110

\section{Publisher's Note}

Springer Nature remains neutral with regard to jurisdictional claims in published maps and institutional affiliations.

\section{Submit your manuscript to a SpringerOpen ${ }^{\circ}$ journal and benefit from:}

- Convenient online submission

- Rigorous peer review

- Open access: articles freely available online

- High visibility within the field

- Retaining the copyright to your article

Submit your next manuscript at $\boldsymbol{\nabla}$ springeropen.com 